Aim of the study: Vitamin D receptor (VDR) expression and serum vitamin D scores in oral premalignant lesions and oral cancer have not been widely analyzed. The role of vitamin D supplementation in advanced oral cancer for improving quality of life $(\mathrm{QOL})$ is also a matter of research.

Material and methods: Vitamin D receptor expression and vitamin $\mathrm{D}$ scores were analyzed in normal oral mucosa $(n=95)$, leukoplakia $(n=23)$ and oral cancer $(n=87) .45$ patients with advanced oral cancer subjected to chemoradiation were evaluated for the effect of vitamin D supplementation on most observable QOL parameters such as oral mucositis, swallowing performance and overall QOL.

Results: Vitamin D receptor expression was increased in oral neoplastic lesions. Vitamin D scores were significantly lower in cases compared to healthy controls $(p=0.002)$. Vitamin D supplementation significantly reduced the therapy-related toxicities in advanced cancer, thus reducing morbidity and improving QOL.

Conclusions: Vitamin D receptor expression is increased in premalignant lesions and oral cancer. Vitamin D insufficiency and deficiency are prevalent in patients with oral neoplastic lesions. Vitamin D supplementation has a role in reducing treatment-related toxicities, especially in advanced cancer.

Key words: calcitriol receptor, calcidiol levels, oral neoplasms, quality of life.

Contemp Oncol (Pozn) 2017; 21 (3): 145-151 DOI: https://doi.org/10.5114/wo.2017.68623

\section{Expression of vitamin $D$ receptor and vitamin D status in patients with oral neoplasms and effect of vitamin $D$ supplementation on quality of life in advanced cancer treatment}

\begin{abstract}
Akshay Anand ${ }^{1}$, Suyash Singh ${ }^{1}$, Abhinav A. Sonkar ${ }^{1}$, Nuzhat Husain ${ }^{2}$, Kul Ranjan Singh ${ }^{1}$, Sudhir Singh ${ }^{1}$, Jitendra K. Kushwaha ${ }^{1}$
\end{abstract}

${ }^{1}$ King George's Medical University, India

${ }^{2}$ RML Institute Of Medical Sciences UP, India

\section{Introduction}

Oral cancer is a major cause of morbidity and mortality worldwide with a low response to chemotherapy and to most standard anticancer drugs. Resistance to the process of regulated cell death is a decisive factor in the carcinogenesis of oral neoplastic lesions and has been held responsible for tumor recurrence as well as chemo- and radiotherapy resistance [1, 2]. Overcoming the resistance is therefore a major challenge to treat oral neoplastic lesions. This has led to an increased effort to identify effective agents that might help in achieving a better response and hence reducing the burden of oral cancer. One such agent is vitamin D, which has been shown to have antiproliferative, anti-invasive properties, and induces apoptosis in a number of tumor cell types including oral squamous cell cancer as well as oral precancerous lesions [3-7]. It is also hypothesized that vitamin D increases the effectiveness of cytotoxic chemotherapy of oral cancer [8].

Palliative care is directed towards minimizing symptoms of adjuvant therapy, relieving suffering and thereby improving the quality of life $(\mathrm{QOL})$. The high frequency of vitamin D deficiency in cancer patients $[9,10]$, the effect of normal vitamin D status on bodily functions [11], mandates efforts to explore its role in oral neoplasms. Since the discovery of an autocrine-paracrine role of local synthesis and signaling of vitamin D in multiple target tissues including prostate, breast and colon [12, 13], studying VDR and corresponding serum vitamin D levels seems to be reasonable for guiding supportive treatment of patients with premalignant lesions and oral cancer.

\section{Material and methods}

It was a prospective observational study conducted in the Department of General Surgery, King George's Medical University Lucknow in collaboration with the Department of Pathology, Ram Manohar Lohia Institute Medical Sciences Lucknow from August 2012 to August 2013 after institutional ethical committee approval (Reference Code: 57 ECM II-B/P11). 110 patients with oral neoplastic lesions (23 oral premalignant lesions (15 diagnosed as "leukoplakia without dysplasia"; 8 diagnosed as "leukoplakia with mild dysplasia"), and 87 cases of invasive oral squamous cell carcinoma) were included in this study and served as "cases". 95 normal healthy, age- and sex-matched individuals unrelated to the patients were recruited to serve as "controls". The mean age of cases was $42.67 \pm 10.83$ years as compared to controls $48.45 \pm 13.48$ years $(p=0.12)$. 
Written informed consent was taken from both cases and controls prior to enrollment. Clinical and pathological data were entered into a pre-structured proforma, which included demographic profile, subsite of the tumor, TNM staging of the tumor (based on AJCC $7^{\text {th }}$ edition 2010) and histological grading. The clinical characteristics of the patients with invasive oral squamous cell carcinoma are detailed in Table 1. Punch biopsy specimens were subjected to histopathological and VDR evaluation. Five milliliters of blood sample was collected through peripheral venous puncture from each case and control for serum vitamin D level (25-hydroxy vitamin D) estimation (using the chemiluminescent immunoassay method).

\section{Technique of VDR estimation}

Slides were fixed overnight at 60 degrees Celsius, dewaxed in xylene, and rehydrated in graded alcohol series. These slides were blocked in $\mathrm{H}_{2} \mathrm{O}_{2}$ methanol and subjected to antigen retrieval. They were incubated with a respective primary antibody (Mouse monoclonal in 1 : 200 dilutions, Abcam, USA, Cat no. ab110106) for an hour and were treated with secondary antibody (Dakopatts, Germany, Cat no. K500711). The sections were incubated with

Table 1. Clinicopathological characteristics of patients with oral squamous cell carcinoma

\begin{tabular}{|c|c|c|}
\hline Characteristics & $\begin{array}{l}\text { No. of } \\
\text { malignant } \\
\text { cases } \\
(n=87)\end{array}$ & $\begin{array}{l}\text { No. of } \\
\text { malignant } \\
\text { cases } \\
(\%)\end{array}$ \\
\hline $\begin{array}{l}\text { Sex } \\
\text { Female } \\
\text { Male }\end{array}$ & $\begin{array}{l}18 \\
69\end{array}$ & $\begin{array}{l}20.7 \\
79.3\end{array}$ \\
\hline $\begin{array}{l}\text { Subsite } \\
\text { Alveolus } \\
\text { Floor of mouth } \\
\text { Buccal mucosa (GB sulcus, cheek, etc.) } \\
\text { Lip } \\
\text { Tongue } \\
\text { Retromolar trigone }\end{array}$ & $\begin{array}{l}09 \\
02 \\
54 \\
03 \\
16 \\
03\end{array}$ & \\
\hline $\begin{array}{l}\text { Primary tumor }(\mathrm{T})^{\star} \\
\text { T1 } \\
\text { T2 } \\
\text { T3 } \\
\text { T4A } \\
\text { T4B }\end{array}$ & $\begin{array}{l}02 \\
20 \\
13 \\
09 \\
43\end{array}$ & \\
\hline $\begin{array}{l}\text { Regional lymph nodes }(\mathrm{N})^{*} \\
\text { N0 } \\
\text { N1 } \\
\text { N2 } \\
\text { N3 }\end{array}$ & $\begin{array}{l}25 \\
41 \\
20 \\
01\end{array}$ & $\begin{array}{c}40.2 \\
47.1 \\
11.5 \\
1.1\end{array}$ \\
\hline $\begin{array}{l}\text { Histological grade }(G)^{\star} \\
\text { G1 } \\
\text { G2 } \\
G^{* *}\end{array}$ & $\begin{array}{l}38 \\
28 \\
21\end{array}$ & $\begin{array}{l}43.7 \\
32.2 \\
24.1\end{array}$ \\
\hline $\begin{array}{l}\text { Anatomic stage/prognostic groups* } \\
\text { II } \\
\text { III } \\
\text { IVA } \\
\text { IVB }\end{array}$ & $\begin{array}{l}02 \\
15 \\
26 \\
44\end{array}$ & $\begin{array}{l}2.3 \\
17.2 \\
29.9 \\
50.6\end{array}$ \\
\hline
\end{tabular}

DAB (3,3'-diaminobenzidine tetrahydrochloride) and were counterstained with hematoxylin, which gave a blue color and was thereafter mounted with DPX.

Slides were examined under a microscope and a minimum of 500 malignant cells counted. Brown stained cells were suggestive of VDR staining (Fig. 1). The number of positively stained cells were counted and recorded as follows: score 0 for nil, score 1 for $1-10 \%$, score 2 for $11-50 \%$, score 3 for $51-80 \%$. For intensity, a score of 1,2 and 3 was given for weak, moderate and strong staining respectively. The immunoreactivity score (IRS) was assigned based on the work of Remmele and Stegner [14]. It was calculated as a product of the staining score and intensity score [score 1 $\times$ score 2]. Slides were considered negative (IRS 0-1), moderately positive (IRS 2-4) or highly positive (IRS 6-12).

\section{Vitamin D score estimation}

Serum vitamin D levels were estimated in blood and each subject was allocated a score taking vitamin D sufficient levels [15] to be the reference base value (Table 2).

Table 2. Vitamin D score

\begin{tabular}{|lc|}
\hline Status (levels of vitamin D) & Vitamin D score \\
\hline Vitamin D sufficient $(30-100 \mathrm{ng} / \mathrm{ml})$ & 0 \\
\hline Vitamin D insufficient $(21-29 \mathrm{ng} / \mathrm{ml})$ & -1 \\
\hline Vitamin D deficient mild $(12-20 \mathrm{ng} / \mathrm{ml})$ & -2 \\
\hline Vitamin D deficient moderate $(6-11 \mathrm{ng} / \mathrm{ml})$ & -3 \\
\hline Vitamin D deficient severe $(<6 \mathrm{ng} / \mathrm{ml})$ & -4 \\
\hline
\end{tabular}

\section{Vitamin D supplementation in advanced oral cancer}

To assess the effect of vitamin D supplementation on quality of life in advanced oral cancer patients, the inoperable/unresectable cases $(n=45)$ were categorized into two groups: Group I (without supplementation, $n=21$ ) and Group II (with supplementation, $n=24$ ). All patients $(n=45)$ were given concurrent chemoradiation (46 Gray in 23 fractions at $200 \mathrm{cGy} /$ fraction/week with cisplatin). In the supplemented group, vitamin D was given in a dose of 1000 IU BD per day [16] for 3 months. Patients were followed up and assessed for change in the quality of life. QOL was assessed on three different scales: the oral mucositis scale (OMS) [17], the swallowing performance status scale (SPSS), and a QOL-based four-point Likert-type categorical scale. [18] OMS parameters included erythema, atrophy, hyperkeratosis, lichenoid changes, edema, ulceration, pseudomembrane, xerostomia and pain. SPSS included difficulty in swallowing from grade 1 to 7 in increasing order of severity. The QOL-based categorical scale included swallowing difficulties, mouth pain, throat pain, chewing difficulties, hoarse voice, sticky saliva, dry mouth, taste difficulties and skin alterations based on a four-point Likert-type questionnaire.

\section{Statistical analysis}

Data were summarized as mean \pm SD. Two independent groups were compared by independent Student's t-test. Two 

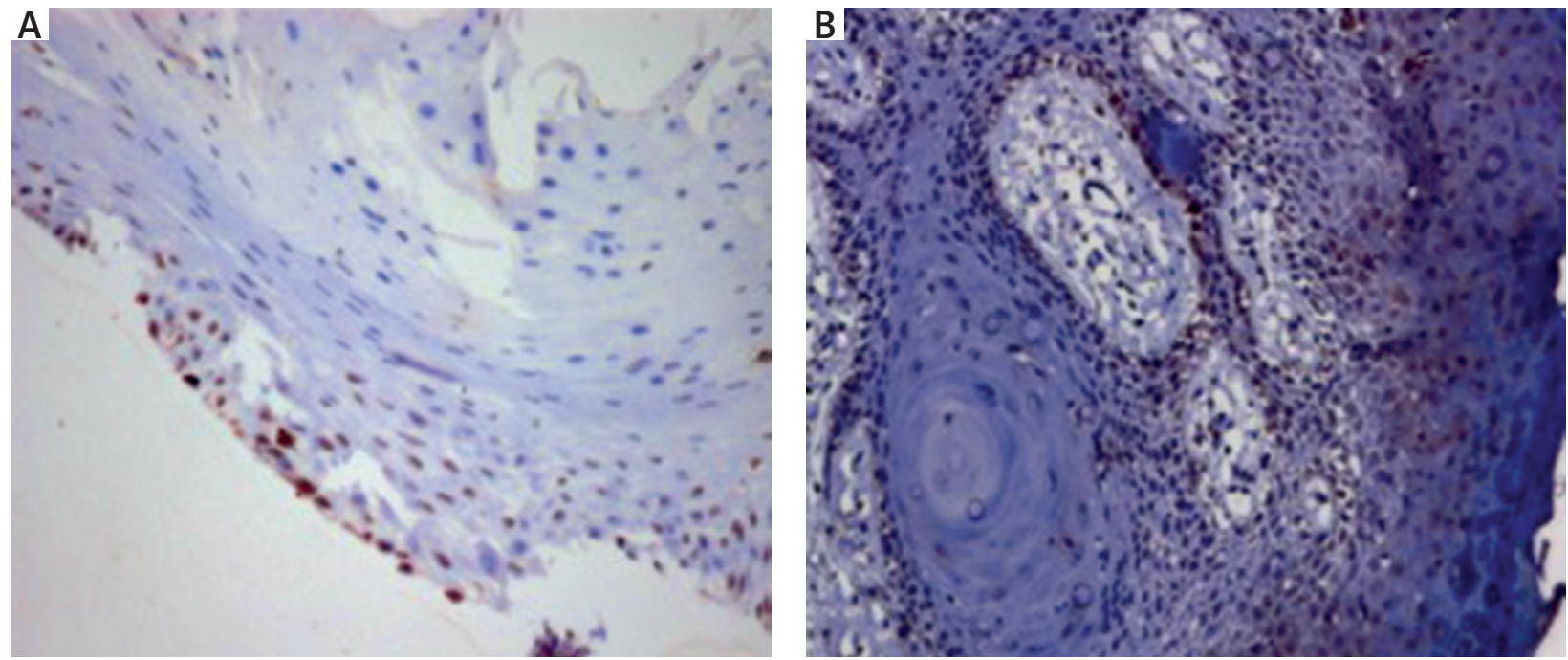

Fig. 1. Vitamin D receptor immunohistochemistry in A) Adjacent epithelium, B) Transition zone and C) Oral squamous cell carcinoma showing an increasing trend in the nuclear expression of vitamin $D$ receptor from $A$ to $C(D A B \times 200 \times$ digital magnification)

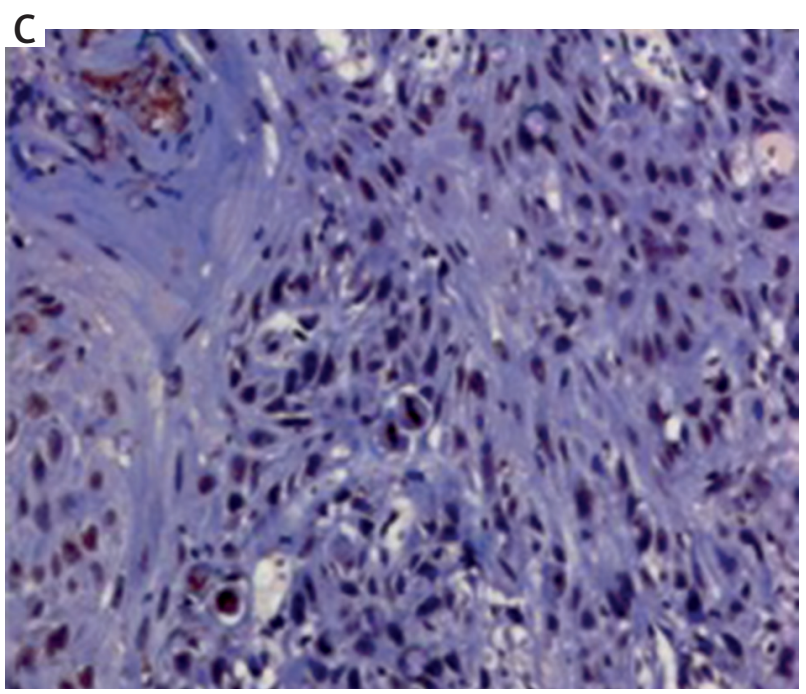

independent groups were also compared by the nonparametric Mann-Whitney U test. Groups were also compared by nonparametric Kruskal-Wallis $(H)$ analysis of variance (ANOVA) by ranks and the significance of differences between the groups was determined by the Z test. Two dependent groups were compared by the Wilcoxon $(\mathrm{W})$ matched pairs test. Discrete (categorical) groups were compared by the $\chi^{2}$ test. A two-sided $(\alpha=2) p<$ 0.05 was considered statistically significant. All analyses were performed on STATISTICA software (Windows version 6.0).

\section{Results}

\section{Vitamin D scores}

Vitamin D deficiency was widely prevalent among cases (84/110; 76.3\%) as well as healthy controls (65/95; $68.4 \%)$. The mean ( \pm SD) vitamin D score of cases $(-1.90$ \pm 0.43 ; range -3 to 0 ) was significantly lower compared to controls $(-1.33 \pm 0.62$, range -2 to 0$)(p=0.002)$.

\section{VDR expression}

The mean percentage of cells stained was significantly lower in cases as compared to controls (1.93 \pm 0.59 vs.
$1.21 \pm 1.12, p=0.013)$. The mean intensity and IRS were found to be higher in cases compared to controls but the difference was not statistically significant (Table 3). IRS significantly decreased with progressing anatomic stages mentioned in AJCC staging (stage II $-4.50 \pm 2.12$; stage III $-4.33 \pm 3.37$; stage IVA $-3.15 \pm 2.66$ and stage IVB -1.27 $\pm 2.07 ; p<0.001)$.

\section{Vitamin D supplementation in advanced oral} cancer

\section{Changes in vitamin $D$ scores}

All patients with advanced oral cancer were deficient in vitamin D scores (range -3 to -1 ). Vitamin D scores of the two groupsare summarized in Table 4. The mean vitamin D scores of the two groups at pre-supplementation were found to be similar; however, after supplementation, the scores in the supplemented group differed significantly from those in the non-supplemented group ( $p=0.013)$. Both groups showed a significant improvement in vitamin D scores after 3 months, and the change in the supplementation group was significantly higher (41.4\%) as compared to the group without supplementation ( $p=0.03$; Table 4). 
Quality of life in advanced oral cancer (Table 5) Oral mucositis scale

Vitamin D supplementation significantly improved erythema, lichenoid, edema, ulceration and pain in patients with inoperable/unresectable oral cancer.

\section{Swallowing performance status scale (SPSS)}

Vitamin D supplementation significantly improved the SPSS scores with improvement in swallowing performance status after three months $(p<0.001)$.

Table 3. Vitamin D receptor expression in cases and controls

\begin{tabular}{lccc}
$\begin{array}{l}\text { Parameters } \\
\text { (mean } \pm \text { SD) }\end{array}$ & $\begin{array}{c}\text { Cases } \\
(n=110)\end{array}$ & $\begin{array}{c}\text { Controls } \\
(n=95)\end{array}$ & p-value \\
\hline \% cells stained & $1.21 \pm 1.12$ & $1.93 \pm 0.59$ & 0.013 \\
\hline Intensity & $1.23 \pm 1.14$ & $1.13 \pm 0.92$ & 0.824 \\
\hline IRS & $2.44 \pm 2.77$ & $2.33 \pm 1.84$ & 0.680
\end{tabular}

\section{QOL-based four-point Likert-type categorical scale}

Vitamin D supplementation significantly $(p<0.001)$ improved the four-point QOL-based Likert-type categorical scale scores over the three-month period.

\section{Discussion}

Vitamin D and its metabolites reduce the incidence of various cancers by inhibiting tumor angiogenesis, stimulating mutual adherence of cells, and enhancing intercellular communication, thereby strengthening the inhibition of cellular proliferation [19]. A low serum level of 25-hydroxy vitamin D, the principal form of circulating vitamin D, is the main marker of vitamin D deficiency [20]. Large-scale population studies have revealed the high prevalence of vitamin D deficiency even in sunshine-rich countries such as India [21-23]. Epidemiologic and case-controlled studies have demonstrated that low vitamin D levels are associated with head and neck cancer risk [24, 25]. In the present work a large proportion of study subjects across both

Table 4. Vitamin D scores of two groups before and after vitamin D supplementation

$\begin{array}{lccc}\text { Groups } & \begin{array}{c}\text { Pre-supplementation values } \\ \text { (mean } \pm \text { SD) }\end{array} & \begin{array}{c}\text { Post-supplementation values } \\ \text { (mean } \pm \text { SD) }\end{array} & \begin{array}{c}\text { Change in vitamin D score } \\ \text { (mean } \pm \text { SD) }\end{array} \\ \begin{array}{l}\text { Group I }(n=21 \text {; without } \\ \text { supplementation) }\end{array} & -1.86 \pm 0.36 & -0.94 \pm 0.80 & 0.89 \pm 0.90 \\ \begin{array}{l}\text { Group II }(n=24 \text {; with } \\ \text { supplementation) }\end{array} & -1.75 \pm 0.53 & -0.29 \pm 0.46 & 1.52 \pm 0.51 \\ p \text {-value } & 0.678 & 0.013 & 0.002\end{array}$

Table 5. Quality of life scores of two groups with advanced oral cancer

\begin{tabular}{|c|c|c|c|c|c|c|c|}
\hline \multirow{2}{*}{$\begin{array}{l}\text { Oral mucositis } \\
\text { scale } \\
\text { individual } \\
\text { parameters }\end{array}$} & \multicolumn{2}{|c|}{$\begin{array}{l}\text { Group I }(n=21) \\
\text { (without vitamin D supplementation) }\end{array}$} & \multicolumn{2}{|c|}{$\begin{array}{l}\text { Group II ( } n=24) \\
\text { (with vitamin D supplementation) }\end{array}$} & \multicolumn{2}{|c|}{ Change in values } & \multirow[t]{2}{*}{$P$-value } \\
\hline & $\begin{array}{c}\text { Pre- } \\
\text { supplementation } \\
\text { values } \\
\text { (mean } \pm \text { SD) }\end{array}$ & $\begin{array}{c}\text { Post } \\
\text { supplementation } \\
\text { values } \\
\text { (mean } \pm \text { SD) }\end{array}$ & $\begin{array}{c}\text { Pre- } \\
\text { supplementation } \\
\text { values } \\
\text { (mean } \pm \text { SD) }\end{array}$ & $\begin{array}{c}\text { Post- } \\
\text { supplementation } \\
\text { values } \\
\text { (mean } \pm \text { SD) }\end{array}$ & $\begin{array}{c}\text { Group I } \\
\text { Mean } \pm \text { SD }\end{array}$ & $\begin{array}{c}\text { Group II } \\
\text { Mean } \pm \text { SD }\end{array}$ & \\
\hline Erythema & $1.71 \pm 0.46$ & $1.48 \pm 0.68$ & $2.08 \pm 0.72$ & $0.79 \pm 0.72$ & $0.24 \pm 0.44$ & $1.29 \pm 0.62$ & $<0.001$ \\
\hline Atrophy & $0.43 \pm 0.51$ & $0.29 \pm 0.46$ & $0.29 \pm 0.46$ & $0.08 \pm 0.28$ & $0.14 \pm 0.36$ & $0.21 \pm 0.41$ & 0.577 \\
\hline Hyperkeratosis & 0.00 & 0.00 & $0.17 \pm 0.38$ & $0.04 \pm 0.20$ & 0.00 & $0.13 \pm 0.34$ & 0.098 \\
\hline Lichenoid & 0.00 & $0.19 \pm 0.40$ & $0.17 \pm 0.38$ & $0.08 \pm 0.28$ & $-0.19 \pm 0.40$ & $0.08 \pm 0.41$ & 0.029 \\
\hline Edema & $1.57 \pm 0.51$ & $1.29 \pm 0.72$ & $1.46 \pm 0.51$ & $0.50 \pm 0.59$ & $0.29 \pm 0.46$ & $0.96 \pm 0.55$ & $<0.001$ \\
\hline Ulceration & $0.52 \pm 0.51$ & $0.86 \pm 0.85$ & $0.71 \pm 0.69$ & $0.25 \pm 0.44$ & $-0.33 \pm 0.48$ & $0.46 \pm 0.59$ & $<0.001$ \\
\hline $\begin{array}{l}\text { Pseudo } \\
\text { membrane }\end{array}$ & 0.00 & 0.00 & 0.00 & 0.00 & 0.00 & 0.00 & - \\
\hline Xerostomia & $0.43 \pm 0.51$ & $0.95 \pm 0.74$ & $0.42 \pm 0.50$ & $0.63 \pm 0.65$ & $-0.52 \pm 0.68$ & $-0.21 \pm 0.72$ & 0.140 \\
\hline Pain & $1.62 \pm 0.67$ & $1.24 \pm 0.89$ & $1.17 \pm 0.48$ & $0.29 \pm 0.55$ & $0.38 \pm 0.50$ & $0.88 \pm 0.61$ & 0.005 \\
\hline SPSS (score) & $4.43 \pm 0.51$ & $4.48 \pm 0.68$ & $5.33 \pm 0.70$ & $4.63 \pm 0.77$ & $-0.05 \pm 0.67$ & $0.71 \pm 0.46$ & $<0.001$ \\
\hline $\begin{array}{l}\text { QOL 4-point } \\
\text { Likert } \\
\text { categorical scale } \\
\text { (score) }\end{array}$ & $8.76 \pm 0.77$ & $8.62 \pm 0.74$ & $9.58 \pm 0.58$ & $7.50 \pm 1.41$ & $0.14 \pm 0.57$ & $2.08 \pm 1.28$ & $<0.001$ \\
\hline
\end{tabular}

${ }^{*}$-value denotes statistical significance of change from pre- to post-supplementation in group I vs. group IIwW 
groups $(76.3 \%$ of cases and $68.4 \%$ of healthy controls) were found to be deficient in vitamin $\mathrm{D}$, with significantly lower mean levels in cases compared to healthy controls. Orell-Kotikangas et al. reported vitamin D insufficiency in $20 \%$ and deficiency in $45 \%$ of head and neck cancer cases. [26] Afzal et al. [27] reported finding that a low plasma vitamin D level was associated with increased risk of tobacco-related cancer including head and neck cancer. Low levels of vitamin $\mathrm{D}$ have also been associated with an increased risk of colon and rectal cancer [28, 29], breast cancer [30], ovarian cancer [31], prostate cancer [32] and esophageal cancers [33].

Ameliorating the symptoms of disease per se and toxicities associated either with chemotherapy or radiation in a palliative setting is of paramount importance. Visacri et al. found in their cohort study that low performance status and tumor progression (T4 stage disease) predict worse QOL and special attention should be given to these patients [34]. The beneficial effect of vitamin D has been supported in a review by Feldman et al. [19] In the present work in advanced cancer patients receiving chemoradiation, in all cases the vitamin D scores were deficient during the pre-supplementation stage. After completion of therapy, after 3 months there was substantial improvement in vitamin D scores of both groups, i.e. Group I without supplementation and Group II with vitamin D supplementation (increase of $0.89 \pm 0.90$ vs. $1.52 \pm 0.51$ in vitamin $D$ score respectively; $p=0.032$ ). A plausible explanation may be that adjuvant therapy resulted in clinical improvement and hence increased oral intake. A report by Ying Gao et al. [35] supports this observation that metabolism of 25-hydroxy vitamin $D$ is not changed by chemotherapy (cisplatin-based) though the levels of 1,25-hydroxy vitamin D are significantly affected.

So far, there is a lack of data on the correlation of beneficial effects of vitamin D with adverse effects during chemotherapy. In the present work three different objective scales were used to assess the impact of vitamin D supplementation on the most observable problems in oral cancer patients due to chemoradiation-induced toxicity, namely oral mucositis, pain, swallowing performance and overall QOL. OMS showed improvement in all nine parameters with significant improvement in erythema (0.24 \pm 0.44 vs. $1.29 \pm 0.62 ; p<0.001)$, lichenoid $(-0.19 \pm 0.40$ vs $0.08 \pm 0.41$; $p=0.029)$, edema (0.29 \pm 0.46 vs. $0.96 \pm 0.55 ; p<0.001)$, ulceration $(-0.33 \pm 0.48$ vs $0.46 \pm 0.59 ; p<0.001)$ and pain scores $(0.38 \pm 0.50$ vs $0.88 \pm 0.61 ; p=0.005)$. These differences may be attributed to the effect of vitamin $D$ in differentiation and epithelization of mucosal cells. Similarly, swallowing performance $(-0.05 \pm 0.67$ vs $0.71 \pm 0.46$; $p$ < $0.001)$ and QOL assessed by the Likert scale $(0.14 \pm 0.57$ vs $2.08 \pm 1.28 ; p<0.001)$ also showed significant improvement with vitamin D supplementation. These findings are in line with the observation first made by Fink et al. that chemotherapy-induced mucocutaneous toxicity can be treated successfully with vitamin D supplementation [36]. However, Kichten et al. in a pilot study observed no difference in chemotherapy-related toxicities between patients with normal and abnormal vitamin D levels [37]. Exclusively designed clinical trials particularly to evaluate the role of vitamin $D$ supplementation with concomitant chemoradiation in advanced cancer are scarce and few. Radiation-induced mucocutaneous problems such as mucositis, hyposalivation, infections, osteonecrosis, etc, are common problems of direct irradiation in oral cancer patients [38]. Delanion et al. noted a decrease in chronic radiation-induced fibrosis combining radiation treatment of head and neck cancer with vitamin D/E and pentoxifylline [39]. Borek reported that antioxidant supplementation during radiotherapy not only prevents tissue damage but also prevents side effects of radiation therapy, thus improving QOL [40]. A recent review in the Journal of National Cancer Institute stated that improving treatment tolerance with antioxidants will enable the patient to complete the full chemotherapy regimen and it would be unethical to disregard the potential benefits of antioxidants in improving patients' ability to tolerate treatments [41]. This inference, well supported by our results, holds much importance in advanced cancer where improving QOL is a primary objective.

VDR is known to influence differentiation, aggressiveness and apoptosis of tumors. [19]. For hormonal receptor immunohistochemistry studies, a semi-quantitative scoring system such as the IRS improves the predictive and prognostic capabilities compared to their qualitative assessment counterparts [42]. In the present study neoplastic oral tissue showed increased VDR expression compared to normal oral mucosa, though the difference was not statistically significant. When correlated with AJCC anatomic stage/prognostic groups, there was a significant decrease in IRS across the stages, indicating the loss of VDR expression with increasing malignant progression. There are very few studies on VDR expression in oral neoplastic tissue in in vivo and ex vivo settings [43]. Published papers hypothesize that calcitriol enhances VDR expression at gene and protein levels in vitro in renal and various non-renal tissues in the body, including the colon [44, 45], breast [46, 47] and prostrate [48]. Moreover, it is thought that inflammatory peptides/cytokines expressed by tumor-infiltrating leukocytes and oral premalignant/ tumor cells also up-regulate VDR expression in adjacent cells [49].

This clinical report has a few limitations of its own. Parameters studied in the three questionnaires such as the pain response are likely to be affected by patient-related variables such as level of education and self-medication. The results observed in the present study of the effect of vitamin D supplementation on quality of life in advanced oral cancer still needs a well designed randomized trial with a long follow-up to generate a better level of evidence.

In summary, the above results demonstrate that vitamin D insufficiency and deficiency are prevalent in patients with oral neoplastic lesions a priori at diagnosis. Because vitamin D deficiency may expose the patients to increased risk of treatment-related morbidity, close attention should be paid to correction of nutritional deficits and especially vitamin D deficiency before treatment, especially in a palliative setting. VDR expression is increased in premalignant lesions and oral cancer.

The authors declare no conflict of interest. 


\section{References}

1. Sinha N, Mukhopadhyay S, Das DN, et al. Relevance of cancer initiating/stem cells in carcinogenesis and therapy resistance in oral cancer. Oral Oncol 2013; 49: 854-62.

2. Grimm M, Schmitt S, Teriete P, et al. A biomarker based detection and characterization of carcinomas exploiting two fundamental biophysical mechanisms in mammalian cells. BMC Cancer 2013; 13: 569.

3. Kornfehl J, Formanek M, Temmel A, Knerer B, Willheim M. Antiproliferative effects of the biologically active metabolite of vitamin D3 (1,25 [OH] 2 D3) on head and neck squamous cell carcinoma cell lines. Eur Arch Otorhinolaryngol 1996; 253: 341-4.

4. Satake K, Takagi E, Ishii A, et al. Anti-tumor effect of vitamin A and $D$ on head and neck squamous cell carcinoma. Auris Nasus Larynx 2003; 30: 403-12.

5. Prudencio J, Akutsu N, Benlimame N, et al. Action of low calce mic 1alpha,25-dihydroxyvitamin D3 analogue EB1089 in head and neck squamous cell carcinoma. J Natl Cancer Inst 2001; 93: 745-53.

6. Meier JD, Enepekides DJ, Poirier B, Bradley CA, Albala JS, Farwell DG. Treatment with 1-alpha, 25-dihydroxyvitamin D3 (vitamin D3) to inhibit carcinogenesis in the hamster buccal pouch model. Arch Otolaryngol Head Neck Surg 2007; 133: 1149-52.

7. Osafi J, Hejazi A, Stutz DD, et al. Differential effects of 1,25-dihydroxyvitamin D (3) on oral squamous cell carcinomas in vitro. J Diet Suppl 2014; 11: 145-54.

8. Dalirsani Z, Farajnia S, Javadzadeh Y, et al. The effects of 5-fluorouracil alone and in combination with 13-cis retinoic acid and vita min D3 on human oral squamous cell carcinoma lines. J Contemp Dent Pract. 2012; 13: 345-50.

9. Dev R, Del Fabbro E, Schwartz GG, et al. Preliminary report: vitamin $D$ deficiency in advanced cancer patients with symptoms of fatigue or anorexia. Oncologist 2011; 16: 1637-41.

10. Stone CA, Kenny RA, Healy M, et al. Vitamin D depletion: of clinical significance in advanced cancer? Support Care Cancer 2011; 19: 865-7.

11. Christakos S, Dhawan P, Verstuyf A, et al. Vitamin D: Metabolism, Molecular Mechanism of Action, and Pleiotropic Effects. Physiol Rev 2016; 96: 365-408.

12. Zehnder D, Bland R, Williams MC, et al. Extrarenal expression of 25- hydroxyvitamin d(3)-1 alpha-hydroxylase. J Clin Endocrinol Metab 2001; 86: 888-94.

13. Thorne J, Campbell MJ. The vitamin D receptor in cancer. Proc Nutr Soc 2008; 67: 115-27.

14. Remmele W, Stegner HE. Recommendation for uniform definition of an immunoreactive score (IRS) for immunohistochemical estrogen receptor detection (ER-ICA) in breast cancer tissue. Pathologe 1987; 8: 138-40

15. Holick MF, Binkley NC, Bischoff-Ferrari HA, et al. Endocrine Society. Evaluation, treatment, and prevention of vitamin D deficiency: an Endocrine Society clinical practice guideline. J Clin Endocrinol Metab 2011; 96: 1911-30.

16. Garland CF, Garland FC, Gorham ED, et al. The role of vitamin D in cancer prevention. Am J Public Health 2006; 96: 252-61.

17. Schubert MM, Williams BE, Lloid ME et al. Clinical assessment scale for the rating of oral mucosal changes associated with bone marrow transplantation development of an oral mucositis index. Cancer 1992; 69: 2469-77.

18. List MA, Siston A, Haraf D, Schumm P, Kies M, Stenson K, Vokes EE. Quality of life and performance in advanced head and neck cancer patients on concomitant chemoradiotherapy: A Prospective Examination. J Clin Oncol 1999; 17: 1020-8

19. Feldman D, Krishnan AV, Swami S, et al. The role of vitamin D in reducing cancer risk and progression. Nat Rev Cancer 2014; 14: 342-57.

20. Holick $M$. The use and interpretation of assays for vitamin D and its metabolites. J Nutr. 1990; 120: 1464-9.

21. Mitra D, Bell N. Racial, geographic, genetic and body habitus effects on vitamin D metabolism. In: Feldman D, Glorieux FH, Pike JW, eds. Vitamin D. San Diego, Calif: Academic Press; 1997: 521-32.

22. Agarwal KS, Mughal MZ, Upadhyay P, et al. The impact of atmospheric pollution on vitamin D status of infants and toddlers in Delhi, India. Arch Dis Child 2002; 87: 111-3.
23. Gupta R, Gupta A. Vitamin D Deficiency in India: Prevalence, Causalities and Interventions. Nutrients 2014; 6: 729-75.

24. Arem H, Weinstein SJ, Horst RL, et al. Serum 25-hydroxyvitamin D and risk of oropharynx and larynx cancers in Finnish men. Cancer Epidemiol Biomarkers Prev 2011; 20: 1178-84.

25. Yuan FN, Valiyaparambil J, Woods M, Tran H, Pant R, Adams JS, Mallya SM. Vitamin D signaling regulates oral keratinocyte proliferation in vitro and in vivo. Int J Oncol 2014; 44: 1625-33.

26. Orell-Kotikangas H, Schwab U, Osterlund P, et al. High prevalence of vitamin D insufficiency in patients with head and neck cancer at diagnosis. Head Neck 2012; 34: 1450-5.

27. Afzal S, Bojesen SE, Nordestgaard BG. Low plasma 25-hydroxyvitamin D and risk of tobacco-related cancer. Clin Chem 2013; 59: 771-80.

28. Wactawski-Wende J, Kotchen JM, Anderson GL, et al. Calcium plus vitamin $\mathrm{D}$ supplementation and the risk of colorectal cancer. $\mathrm{N}$ Engl J Med 2006; 354: 684-96.

29. Tangrea J, Helzlsouer K, Pietinen P, Taylor P, Hollis B, Virtamo J, Albanes $D$. Serum levels of vitamin D metabolites and the subsequent risk of colon and rectal cancer in Finnish men. Cancer Causes Control 1997; 8: 615-25.

30. Rossi M, McLaughlin JK, Lagiou P, et al. Vitamin D intake and breast cancer risk: a case-control study in Italy. Ann Oncol 2009; 20: 374-8.

31. Lefkowitz ES, Garland CF. Sunlight, vitamin D, and ovarian cancer mortality rates in US women. Int J Epidemiol 1994; 23: 1133-6.

32. Hanchette CL, Schwartz GG. Geographic patterns of prostate cancer mortality. Evidence for a protective effect of ultraviolet radiation. Cancer 1992; 70: 2861-9.

33. Lipworth L, Rossi M, McLaughlin JK, Negri E, Talamini R, Levi F, Franceschi S, La Vecchia C. Dietary vitamin D and cancers of the oral cavity and esophagus. Ann Oncol 2009; 20: 1576-81.

34. Visacri MB, Ferrari GB, Pimentel R, Ambrósio RD, Lima CS, Mazzola PG, Moriel P. Evaluation of the quality of life of patients before treatment of squamous cell carcinoma of the head and neck by means of chemoradiotherapy. Contemp Oncol (Pozn) 2015; 19: 148-53.

35. Gao Y, Himizu M, Amada S, Ozaki Y, Aso T. The effects on vitamin of chemotherapy D metabolism including cisplatin. Endocr J 1993 ; 40: 737-42.

36. Fink $M$. Vitamin D deficiency is a cofactor of chemotherapy-induced mucocutaneous toxicity and dysgeusia. J Clin Oncol 2011: 29: e81-2.

37. Kitchen D, Hughes B, Gill I, O'Brien M, Rumbles S, Ellis P, Harper P, Stebbing J, Rohatgi N. The relationship between vitamin D and chemotherapy-induced toxicity - a pilot study. Br J Cancer 2012; 107: 158-60.

38. Dobroś K, Hajto-Bryk J, Wróblewska M, Zarzecka J. Radiation-induced caries as the late effect of radiation therapy in the head and neck region. Contemp Oncol (Pozn) 2016; 20: 287-90.

39. Delanian S, Balla-Mekias S, Lefaix JL. Striking regression of chronic radiotherapy damage in a clinical trial of combined pentoxifylline and tocopherol. J Clin Oncol 1999; 17: 3283-90.

40. Borek C. Antioxidants and radiation therapy. J Nutr 2004; 134: 3207S-3209S.

41. Block K, Koch A, Mead M, et al. Re: Should Supplemental Antioxidant Administration Be Avoided During Chemotherapy and Radiation Therapy? J Natl Cancer Inst 2009; 101: 124-5; author reply 125-6.

42. Brouckaert O, Paridaens R, Floris G, Rakha E, Osborne K, Neven P. A critical review why assessment of steroid hormone receptors in breast cancer should be quantitative. Ann Oncol 2013; 24: 47-53.

43. Grimm M, Cetindis M, Biegner T, Lehman M, Munz A, Teriete P, Reinert S. Serum vitamin D levels of patients with oral squamous cell carcinoma (OSCC) and expression of vitamin D receptor in oral precancerous lesions and OSCC. Med Oral Patol Oral Cir Bucal 2015; 20: e188-95

44. Delvin EE, Lopez V, Levy E, Menard D. Developmental expression of calcitriol receptors, 9-kilodalton calcium-binding protein, and calcidiol 24-hydroxylase in human intestine. Pediatr Res 1996; 40: 664-70.

45. Huerta S, Irwin RW, Heber D, Go VL, Koeffler HP, Uskokovic MR, Harris DM. 1alpha,25-(OH)(2)-D(3) and its synthetic analogue de- 
crease tumor load in the Apc(min) mouse. Cancer Res 2002; 62:

741-6.

46. Eisman JA, Martin TJ, Maclntyre I, Moseley JM. 1,25-dihydroxyvitamin-D receptor in breast cancer cells. Lancet 1979; 2: 1335-6.

47. Colston KW, Berger U, Wilson P, et al. Mammary gland 1,25-dihydroxyvitamin D3 receptor content during pregnancy and lactation. Mol Cell Endocrinol 1988; 60: 15-22.

48. Miller GJ, Stapleton GE, Hedlund TE, Moffat KA. Vitamin D receptor expression, 24-hydroxylase activity, and inhibition of growth by 1alpha,25- dihydroxyvitamin D3 in seven human prostatic carcinoma cell lines. Clin Cancer Res 1995; 1: 997-1003.

49. Reichrath J, Rafi L, Müller SM, et al. Immunohistochemical analysis of 1,25-dihydroxyvitamin D3 receptor in cervical carcinoma. Histochem J 1998; 30: 561-7.

\section{Address for correspondence}

\section{Abhinav Sonkar}

Department of Surgery

King George's Medical University India

Shahmina Road

226003 Lucknow, India

e-mail: abhinavarunsonkar@gmail.com

Submitted: 21.02 .2017

Accepted: $\quad 9.04 .2017$ 